\title{
The HISTORY OF UNIVERSITY MIDWIFERY TrainING IN KRAKOW IN THE YEARS 1780-1918 IN THE CONTEXT OF HISTORICAL AND ORGANISATIONAL CONDITIONS
}

\author{
Małgorzata Kazimiera Dziedzic ${ }^{\mathrm{A}, \mathrm{D}}$, Elżbieta Sibiga ${ }^{\mathrm{B}, \mathrm{F}}$, Małgorzata Dziubak ${ }^{\mathrm{B}, \mathrm{E}}$, Paula Janczyk ${ }^{\mathrm{C}, \mathrm{E}}$
}

Laboratory of Fundamentals in Obstetric Care, Institute of Nursing and Midwifery,

Faculty of Health Sciences, Jagiellonian University Medical College, Krakow, Poland

Authors' contribution:

A. Study design/planning • B. Data collection/entry $\bullet$ C. Data analysis/statistics $\bullet$ D. Data interpretation $\bullet$ E. Preparation of manuscript $\bullet$ F. Literature analysis/search $\bullet$ G. Funds collection

\author{
Address for correspondence: \\ Małgorzata Kazimiera Dziedzic \\ Laboratory of Fundamentals in Obstetric Care \\ Institute of Nursing and Midwifery \\ Faculty of Health Sciences \\ Jagiellonian University Medical College \\ 58 Zamoyskiego St. \\ 31-523 Krakow, Poland \\ e-mail: malgorzata.dziedzic@uj.edu.pl \\ SUBMITTED: 17.03 .2020 \\ ACCEPTED: 30.03 .2020 \\ DOI: https://doi.org/10.5114/ppiel.2020.96090
}

\begin{abstract}
Midwifery training in Krakow started within the University structures and was closely related to the reform of the Academy in 1780. Following H. Kołłątaj and Prof. A. Badurski's ideas, the first clinical hospital was created in Krakow, where midwifery training started. Prof. R. Czerwiakowski gave lectures for midwives and supervised the maternity clinic. The changing political relations remodelled the structure and organisation of the school authorities, which affected the working conditions of the University. Obtaining a diploma was preceded by the so-called strict exam in front of an exam board consisting of professors. The positive result of the exam then authorised the student to take an oath in front of the Dean, the secretary, and a professor of the Faculty of Medicine, which, as stated on the diploma, gave "the right to practice midwifery". Following professors and heads of the maternity clinic made special efforts in organising midwifery courses and improving continuously difficult learning conditions. Many documents issued to midwives or provided by midwifery students have survived from their professional activity. Prof. H. Jordan achieved outstanding results in this respect, as he managed to obtain permission from the partitioning authorities to organise an independent midwifery school. It opened in 1895, and Prof. A. Mars became its head. The importance of achieving this idea promoted by Prof. $\mathrm{H}$. Jordan for the further development of midwives in Krakow is worth emphasising. The independent institution took the name of the Imperial Royal School of Midwives.
\end{abstract}

Key words: midwife, Main Crown School, Kołtątaj, St. Lazarus Hospital, Prof. H. Jordan.

\section{INTRODUCTION}

The Faculty of Health Sciences of the Medical College of the Jagiellonian University is the forerunner of the rich tradition of midwifery education in Krakow. It was initiated within the University structures and was closely associated with the structures of the Jagiellonian University for more than the first hundred years. Later there came the period of independence of the midwifery school, with multiple changes to the name, the seat, the governing bodies, the requirements for candidates, and the teaching staff. In the academic year 2005/06, midwifery training returned to the structures of the University and is now a twocycle programme.

The beginning of midwifery training at the University of Krakow, which in 1780 was called the Main Crown School [Szkoła Główna Koronna], was closely associated with the reform of the decrepit Academy and the new education system in Poland, which developed after cassation of the Jesuit order and the reforms of the National Education Commission established in 1773. Following the spirit of Enlightenment, the Main Crown School was to disseminate European academic achievements, especially those that had practical applications, to pursue secular and civic education, which was hoped to offer a chance of raising the country from progressing economic decline [1]. These were the times of the proceeding collapse of Poland, which gradually lost its territory in three subsequent partitions.

In 1780, the University received the abovementioned name: Main Crown School, and both Main Schools existing at the time: the Krakow University and the Vilnius University, were to take over responsibility for the form of, and supervise the education 
system of, the First Commonwealth. The creation and introduction of a new concept of the internal organisation of the University were commenced by a former student of the Krakow Academy, a young, only 26-year-old canon of the Krakow chapter, Hugo Kołłątaj. He also studied abroad, in Rome and Vienna, where he became acquainted with the latest achievements of European science. He presented the memorandum On the Introduction of Good Education to the Krakow Academy and the Establishment of a School for Teachers of Regional Schools to the president of the National Education Commission [Komisja Edukacji Narodowej], bishop Michał Poniatowski. He devised a revolutionary, carefully prepared plan to reorganise Krakow University to provide graduates with professional preparation and to become an academic research centre. Bishop Poniatowski, the brother of King Stanisław August, was aware that the level of the whole education system depended on modern, well-managed universities, so he endeavoured to review the then teaching system and financial status of the Krakow Academy. Kołłątaj, a well-prepared resolute man, uncompromising in his reform activity, was assigned to this task. He was also appointed as a member of the Society for Elementary Books, a body of the National Education Commission dealing with curricula and editing textbooks. Soon Canon Kołłątaj was delegated by the Commission to reform his Almae Matris [1, 2].

Following the suggestions he received from the National Education Commission, he began the reform with Nowodworski Schools [Szkół Nowodworskich], which were preparatory schools closely connected to the Krakow Academy, and with assessing the situation of the Krakow Academy. After reforming the Nowodworski University Schools, Kołłątaj began reorganising the system of studies at the Faculties of Philosophy, Theology, and Medicine, and as a consequence, he began the reform of these faculties [3-5].

In 1780, the University reform was completed. However, the final reorganisation of the University was only approved by the Acts of the National Education Commission for the academic social class, made public in 1783. In 1783 the Main Crown School [Szkoła Głowna Koronna] replaced the faculties with the socalled Colleges: Physical and Moral. The colleges were divided into Schools. The Physical College included a significantly expanded and modernised Medical School, covering Anatomy and Physiology, Surgery and Obstetrics, Pharmacy and Medical Matter, and Pathology and Medical Practice, as well as a school of Mathematics and a school of Physics. An anatomical dissection room, a botanical garden, and a clinical hospital were planned to be launched at the Medical School.

The reform of the former Faculty of Medicine was carried out by Kołtątaj according to the plan devised by Prof. Andrzej Badurski, an outstanding specialist in the field of medical sciences. Badurski reorganised the Department of Anatomy at the University (he became the head of that department), and he also pointed out that establishing a dissection room and an anatomical museum was necessary. Creating proper conditions for training doctors and starting midwifery training must also be attributed to a large extent to Prof. Andrzej Badurski participating in the reform. According to his proposal, 2-3-month training was planned "for women who want to devote themselves to this profession" $[4,6]$. It was on his initiative and effort that in 1780, following the example of other European universities, the first clinical hospital in Poland, comprising Medicine, Surgery, and Obstetrics, was organised. Professor Badurski was convinced that none of the hospitals (or rather asylums) existing in Krakow at that time would meet the expectations of the planned clinic, so it was decided to adapt quite modest rooms in the former Jesuit College of St. Barbara [7]. It was called the Academic Hospital, while in the foundation act of the National Education Commission these clinics were referred to as "Hospital for the Barber-Surgeon School". Badurski became its head. It was the largest venture in the doctor's life. Such a centre allowed medical students to learn the methods of treatment in practice. Thus, very early in history, the Krakow Medical School began to teach medicine in a very modern way, using demonstrations, practical activities, and observations in educational practice, which were shaped on the Western European clinics. The development of midwifery education in Krakow was closely linked with the organisation of the maternity clinic at that time [8].

The supervision and running of the maternity clinic were entrusted to Rafał Czerwiakowski, a professor of surgery, obstetrics, and later also anatomy, who was the first to conduct lectures in $\mathbf{1 7 8 0}$ for females who wanted to provide care to women in childbirth and after childbirth. Along with pharmacy students, these were essentially the first women to take fulltime education at university. It is not known, however, whether it was in 1780 that the first midwifery students appeared at the Medical School, because no relevant documents could be found.

Lectures lasted 1.5 hours daily and were delivered from March till the summer holiday. The obstetric phantom imported from Vienna, which was a phantom with two children for teaching postnatal care, was used to train midwives. Rafat Czerwiakowski was the first to lecture in Polish. The proof of his care for the training of midwives and surgeons was the number of medical instruments the Barber-Surgeon School possessed, as shown by the preserved inventory from 1785. The first Polish obstetric terminology is also Prof. Czerwiakowski's contribution $[9,10]$. 
For the first 15 years, training for midwives was conducted jointly with lectures for medical students. Every year, only a few women wanting to learn midwifery applied to be admitted. More complete and orderly lists of students that have been preserved in the archives date back only to the year 1786/87 [11].

There were at least a few reasons for the initially small number of women learning midwifery. Serious obstacles for some women wishing to learn this profession were the need to pay tuition fees, inability to read and write, as well as the lack of statutory requirements related to the need to have a certificate (patent) for the right to provide such services among women. In training midwives, it was also necessary to overcome the difficulties arising from a shortage of women who wanted to have a delivery in the clinic. A solution to this issue was the idea of finding unmarried and homeless pregnant women, who were guaranteed by the relevant act obtained in the municipal office that they would not be subject to imprisonment and removal from the city. This privilege was also of great social importance, overcoming the brutal laws and social ostracism towards these women $[12,13]$.

The hospital was equipped and launched thanks to subsidies from the National Education Committee, numerous bequests obtained, among others thanks to Badurski's efforts, as well as his personal, substantial donation for this purpose. To increase the training capacity by increasing the number of beds, of which there were originally three - including one obstetric bed, Badurski decided to connect the Sisters of Mercy hospital with the academic hospital. Six sisters from this hospital were transferred to the university hospital and the number of beds increased by five. Badurski's subsequent efforts in this regard rendered a further increase, and thus in 1786 the hospital had 16 beds [14-16].

Together with the increasing scope of the assistance provided in the clinical hospital and opening within its premises, among others, an anatomy room, a pharmacy, and a dissecting room, the conditions for practical training deteriorated due to inefficient space. Prof. Badurski, aware of the worsening perspectives for the proper functioning of the clinic operation, wanting to change the location (due to the proximity of slaughterhouses and the gutter on the Small Market Square) and improve the size of the premises, made efforts to obtain another building, larger and more adequately located [17].

Owing to the efforts of the National Education Commission, which appreciated the role of the first Krakow clinic in practical training of students, this endeavour proved successful. Hence, in 1787 the building of the monastery of Discalced Carmelites was purchased in the suburb of Wesola (today Kopernika Street) [18], to which the clinic was moved. It was called the hospital of St. Lazarus (foundation act 9 April 1788). Since that time the district and its main street, which in the early nineteenth century would take the name of Nicolaus Copernicus, has been the centre of university medicine in Krakow. However, little space was allocated to the clinics in the acquired monastery building. There were only 24 beds, four of which were allocated to the maternity clinic. The rest of the hospital was supervised by the managing doctor and had a department of surgery and internal medicine, obstetrics, a wet-nurse ward, an abandoned infant ward, and a neonatal ward (the latter two moved from the Holy Spirit Hospital) [19].

Thus, the new location of the hospital improved the working conditions of the clinics to a very small extent. The rooms in the new place were small, cramped, run-down former monastic cells. Besides, the functioning of the clinics was disrupted by competence disputes related to the management of the hospital between the Sisters of Charity working there and the professors.

The functioning of the Medical School became increasingly difficult in the conditions of the collapse of statehood, the Kosciuszko insurrection, and the lack of effectively functioning systemic solutions. Moreover, warfare activities distracted young people from academic pursuits.

The number of women learning obstetrics was still small but increasing. In the year 1790/91, it comprised 10 women and in 1791/92 as many as 16 . They came from Krakow Province. The tuition fee of one student was funded by Duchess Radziwiłt née Lubomirski; the other nine studied at their own expense. This is confirmed by some sources from the eighteenth century stating that "some studied at their own expense, others were funded by the affluent of that time, e.g. Duchess Radziwiłł née Lubomirski” [20].

The age of the women who studied was very diverse, the youngest of them, Teresa Łuszczewska, was 19, and the oldest, Katarzyna Szczerbińska, was 50 years old. Three studied in their first year, five of them in their second, and the remaining two in their third year. It follows that the course at that time was extended to three years.

The women completing the obstetrics course took the exam and only then received the aforementioned so-called school-leaving patent [21].

The certificates that they received specified the treatments they were allowed to perform, and the obligation to call a doctor if needed. The report by Hugo Kołłątaj testifies that by 1784 only a few women had received it. Professors Andrzej Badurski and Rafał Czerwiakowski requested that the Magistrate issue orders regarding the necessity of having such patents by professions of barber-surgeon and midwife, which would increase the number of women in training, and thus would help attain the goal of 
providing the society with trained midwives to help women giving birth almost exclusively at home. The Krakow authorities issued such an order, which meant that the doulas, who provided such services, began to apply for the course. The university also often relieved poor students of the necessity to pay for the exam. The lack of means had to be confirmed by an appropriate statement, e.g. by the parish priest or the senior of the guild. Classes were held every day from March to June for an hour and a half [22-24].

The Third Partition of Poland after the collapse of the Kosciuszko Uprising brought an end to the development of the Main School in the spirit of the Kołłąaj reforms. The time of the third partition radically changed the conditions of the school's functioning. After the beginning of the Austrian rule in Krakow in 1796, the Main School was systematically forced by the Austrian authorities to adapt their curricula and teaching system to the structure that existed in other Austrian universities. The University, subordinated to the Viennese administrative authorities, lost its autonomy, financial independence, and finally the opportunity to lecture in Polish, which was replaced by Latin and German [19, 25].

The first decrees regarding medical studies under Austrian rule began to appear as early as in 1797 and concerned the method of examination and the procedure for issuing certificates, which were to be similar to those applicable to pharmacists, surgeons, and midwives in Austria. The Court Commission in Vienna, to which the University was subordinated, issued a regulation regarding the establishment of a new Department of Practical Surgery and Obstetrics in 1799. In the academic year 1802/03, the School of Medicine already constituted a separate Faculty of Medicine, with an increased number of departments (apart from the already existing ones, a Practical Obstetrics Department was established, among others). In addition to the Faculty of Medicine, three others were introduced, and thus in 1803 the Physical and Moral Colleges ended their operation. The new structure of the organisation led to the division of the institute into higher, Medical, in which the language of instruction was Latin and lower, Barber-Surgeon, in which the language of instruction was Polish $[3,10]$.

These changes were also followed by changes in the teaching staff. The courses for midwives were organised by a German, Prof. Frederic Colland, who was entrusted with running the newly established Practical Midwifery Department. He made special efforts to organise the courses for midwives properly, which at that time covered six months of theory and two months of clinical practice. Latin was generally the language of instruction, and only classes in courses for surgeons, midwives, and pharmacists were delivered in Polish. Because the lectures given by Prof. Colland for midwives were shared with medical students, they were held in Latin, and one of the assistants translated them for midwifery students. Theoretical Midwifery for midwives and surgeons was delivered in Polish by Sebastian Girtler, who substituted for Rafat Czerwiakowski due to the latter's poor health. All aspects of the required care for patients in the clinic were provided by midwifery students and surgical students under the guidance of a qualified hospital midwife. The maternity clinic was located on the first floor and, according to Prof. Colland, had the most severe limitations in the size of premises. As the socalled "hospital physicist", he began efforts to obtain new premises for this clinic. His efforts, unfortunately, were unsuccessful [26-28].

At the end of 1809, the enlarged Duchy of Warsaw took over the rule of Krakow, and thus the University through the Educational Chamber, which began to rebuild the organisational structure of Almae Matris again. Thus came the next exchange of the teaching staff. The introduced changes caused organisational and staff instability of the University [3, 29].

The number of departments was reduced, and the German professors who had been brought to Krakow were replaced by Polish ones. The medical clinic was taken over by Prof. Kostecki, and one of his assistants was Ignacy Woźniakowski, who in 1811 took the position of Professor of Obstetrics and Diseases in Women and Children. He delivered lectures in Theoretical Obstetrics, while Practical Obstetrics was instructed by Mikołaj Cordé. The organiSation of practical obstetrics at the time accepted that each delivery would be assisted by one medical student, one obstetrics student, and one trainee midwife. Ignacy Woźniakowski devoted a lot of attention and effort to the training of midwives. Many documents issued to midwives or provided by midwifery students have survived from that period.

We can learn from them that literacy and moral conduct were required from midwifery students. The files of students from this period contain such certificates, issued by the city authorities or by homeowners [30]. The number of women studying midwifery at the beginning of the nineteenth century was still small. The Provost Walenty Litwiński's report from the year 1816/17 lists six certified midwives. Three years later, in 1820, only four obstetrics students were listed: Okrąglicka Barbara, Olszewska Petronela, Pawlikowska Agnieszka, and Ptaszyńska Anna. Obtaining a diploma meant not only completing the theoretical and practical course in the field of midwifery but also passing a strict exam in front of a board consisting of the Dean of the Faculty of Medicine and its professors, which took place at the written request of the interested student. The positive result of the exam then authorised the student to take an oath in front of the Dean, the secretary, and a professor of the Faculty of Medicine, which, 
as stated on the diploma, gave "the right to practice midwifery" [12, 30, 31]. This is confirmed by the content of one of the many documents preserved in the Jagiellonian University archives:

As of today Ms. Czekańska (Zofia - author's note), Candidate of Midwifery Art, passed the Examena Rigorosum in front of the undersigned examiners, therefore she is allowed to take the oath of the midwife. This took place in Krakow on October 24, 1810. Signed Franciszek Kostecki and Józef Jaworski [30].

After the fall of the Duchy of Warsaw and the advent of the Republic of Krakow, which was under the strict control of the three partitioning "guardian courts", a thirty-year period followed, which was not very favourable for the University's development. Just at that time, in the academic year 1817/18, the oldest Polish university acquired the name "JagielIonian University", which is still used today (introduced 5 August 1815). The teaching staff in the Medical Department gradually changed. It started with Prof. Franciszek Kostecki re-taking administration of the medical clinic, then during subsequent administration periods by Dr. Wojciech Boduszyński, Ignacy Linhard, and Józef Maciej Brodowicz, efforts were made to move the clinics from St. Lazarus Hospital to a new building. St. Lazarus Hospital was cramped, many rooms did not meet basic sanitary requirements, and they were dark and insufficiently ventilated. Mortality also increased among the patients treated. There were still terrible staff relations due to the ongoing disputes between the Sisters of Mercy and university professors regarding the right to administer the hospital and use it for scientific purposes [19, 32].

Particularly determined attempts to move the clinics from St. Lazarus Hospital were made by Prof. Maciej Brodowicz when he became the Clinical Professor at that hospital in 1823.

A strong argument about the need for the clinical wards to be moved to a new building was provided not only by the catastrophic situation of the hospital described above but also by the outbreak of typhoid fever in the city. Its source was seen in St. Lazarus Hospital [14, 33].

It was then decided that the clinics were to be moved to the building donated to the Jagiellonian University by members of the dissolved Freemasonry Society, located in the gardens at Kopernika Street. After appropriate reconstruction, all three clinics were moved, and they were officially opened on 22 November 1827 . These rooms were more comfortable, but still insufficient for the real needs of the three clinics.

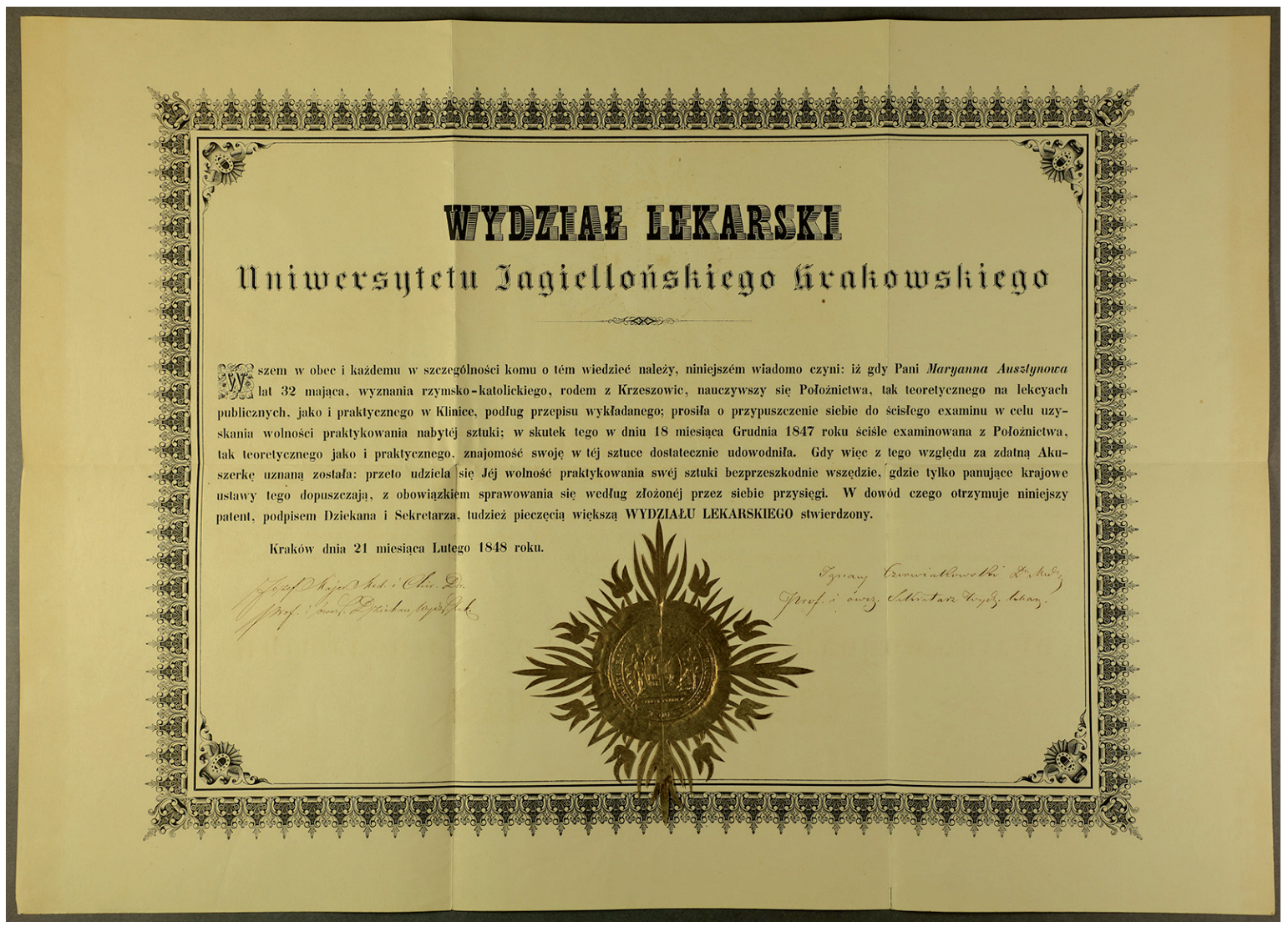

Figure 1. A graduation certificate issued by the University Midwifery School in 1847 


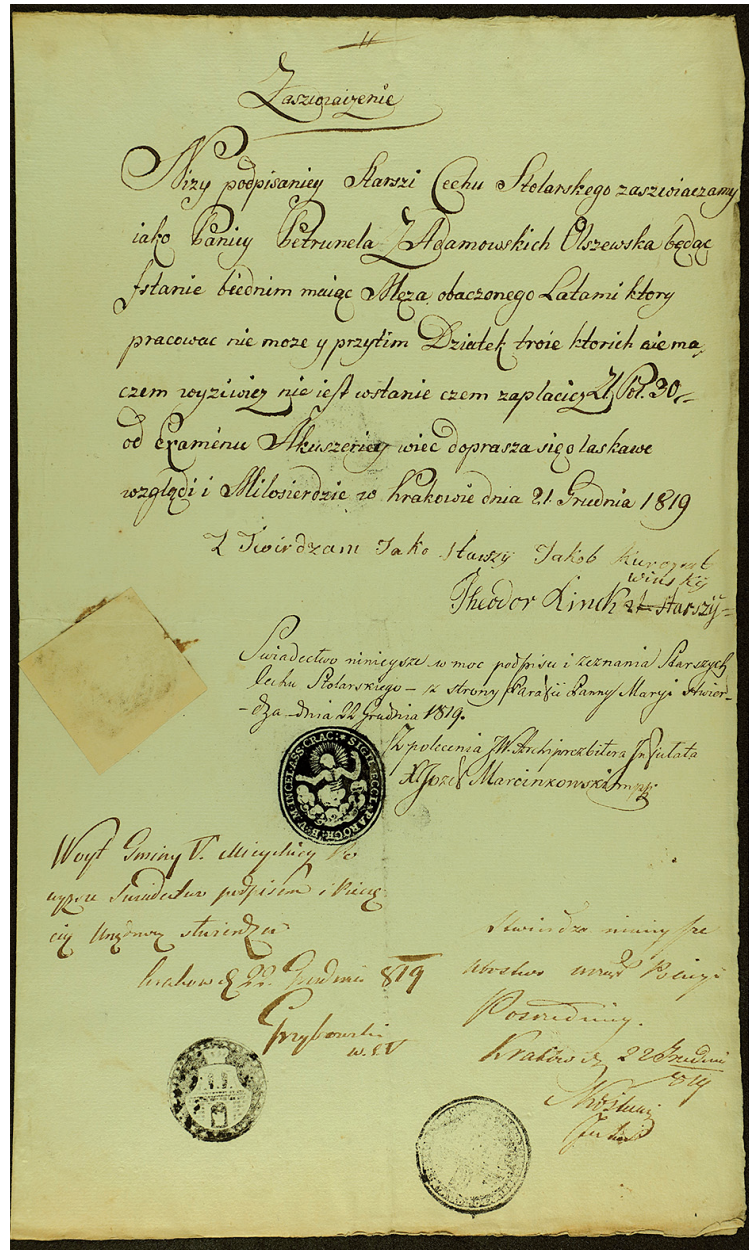

Figure 2. A certification of insufficient means attached to the request for exemption from fees for the final exam, which entitled a student to obtain the so-called "midwife's patent"

Prof. Brodowicz was also the main initiator of the reform regarding the management of St. Lazarus Hospital, especially since soon after the opening of the clinical wards in the new premises, they proved to be insufficient and efforts were made to return the maternity clinic to St. Lazarus Hospital, which took place in 1836. The decisions of the partitioning government, after the annexation of Krakow by the Austrian partitioning forces and the liquidation of the Republic of Krakow, contributed to this. But luckily, before that, in 1839 a new statute establishing a supervisory authority was introduced. The supervisory board for hospitals of the Republic of Krakow dealt with the reorganisation of the hospital, which greatly influenced not only the improvement of hospital relations but above all the level of care over patients [32, 34]. At that time, the maternity clinic and the abandoned infant facility, as well as a professor, also had one assistant, a midwife, and male and female trainees. The enlarged maternity clinic had seven rooms at that time (former monastic cells) with 17 beds, including five for women in labour, a lecture room, a bathroom, and new equipment.

When the maternity clinic returned to St. Lazarus Hospital, where it remained until January 1870, Prof. Józef Teofil Kwaśniewski began to deliver his lectures. In 1833, after a reform that merged Obstetrics, Gynaecology, and Paediatrics into one department, Prof. Kwaśniewski was appointed "a public professor of theoretical and practical obstetrics, gynaecology, and paediatrics, and the head of the maternity clinic, women's and children's diseases department, and the abandoned infant department at St. Lazarus Hospital". Then, after a transition period with a three-year training course for future midwives, a new system was introduced with a two-year period of theoretical study and a four-month practical training. The provisions concerning candidates were also specified. They required the applicants to be able to read and write and have a certificate of moral conduct [32, 35].

Prof. Kwaśniewski took great care of the efficient organisation of work, and regularly conducted practical classes and lectures. It is to his research and scientific work that we owe, among others, determining the duration of particular stages of delivery. He was the first in Krakow to begin using chloroform for anaesthesia during delivery [35].

The maternity clinic held practical classes for surgery and obstetrics students. They covered all aspects of care of patients, and the students' practical training was led by a qualified hospital midwife, known as the institution midwife.

An increase in the requirements for obstetric care over women giving birth is demonstrated by an instruction issued in 1842 in which, among others, we read: "The midwife is obliged to strictly adhere to the principles of obstetric art and, without stopping at the knowledge obtained at school, is supposed to revise the knowledge and refresh her memory, because this is the only way she can gain experience and rightly win the trust of the public" [36]. Ten years later, a decree of the Ministry of the Interior, again under the rule of the Austrian government, was issued dated 6 March 1854, Statutes Log no. 57, prohibiting, on pain of a fine or even arrest, unqualified women to work in towns where qualified midwives were available.

In 1863, after Kwaśniewski left the Department of Obstetrics, Dr. Maurycy Madurowicz took over the management of the $1^{\text {st }}$ Obstetrics Clinic as well as the Theoretical and Practical Obstetrics in Krakow. His several years of efforts to improve the standard of the premises led to the purchase by the University of the so-called Brodowicz manor house (no longer existing today) at Kopernika Street. One floor was added to the manor house, and one of the wings was extended. After this reconstruction, in the years 
1869-1870, the Gynaecology and Obstetrics Clinic was established in the building, where it remained until 1936. Madurowicz stopped the practice, which was previously followed by some professors, of delivering lectures in the clinic sick rooms - he moved all lectures to the rooms of Collegium Minus at Gołębia Street. It was in the same academic year that Polish became the only language of instruction [29]. A manifestation of his concern for training midwives was, among others, his textbook published two years later called "Learning Obstetrics for the Use of Midwives", which for many years was a valued source of knowledge for both studying and practicing midwives. Prof. Madurowicz underestimated the findings of I. P. Semmelweis because he considered the use of carbolic acid for disinfection harmful, but he recommended maintaining far-reaching hygiene in obstetric and gynaecological procedures [37].

Professors of the Faculty of Medicine appreciated the role of trained midwives, which they played in caring for women and children. This is confirmed by, among others, an appeal issued by the Faculty in 1869 , in which women were encouraged to learn this profession. In addition to the previously required literacy and basic mathematic skills, candidates had to be married or widowed and pass the entrance examination. The training course then lasted, as before, two years, including practical training. In response to the appeal, to increase the number of women in training, particular municipal authorities proposed to fund one student's training each year.

In 1870 Dr. Henryk Jordan began working for Prof. Madurowicz as an assistant in the maternity clinic and often substituted for him delivering lectures.

After Prof. Maurycy Madurowicz died in 1895, Prof. Henryk Jordan became the professor of gynaecology and obstetrics and the head of the clinic. He was an excellent and valued doctor, lecturer, and social worker. He also accepted the discovery of I. P. Semmelweis regarding the causes of puerperal fever, which he expressed in the third edition of the textbook "Learning Obstetrics for the Use of Midwives" (1892), introducing the terms aseptic and antiseptic. The contents of the introduction and individual chapters show that for Prof. Jordan the most important things were the level of knowledge of trained midwives as well as their moral standards. He also appreciated their hard work [37].

In the introduction, the author wrote:

(...) but the vocation is no less difficult. From the moment when the midwife is called to the woman in labour, she is responsible for the health of the mother and child, which the family trusts in her care. This matter is of great importance and such trust must be answered by every midwife with her best effort.

The handbook included not only content in the field of obstetrics, but some so-called extras, among others: midwife's oath, ministry's instructions for midwives, and a model delivery report.

The professional work of the midwives trained at the Krakow School was regulated by procedures and instructions issued by the authorities, detailing all issues related to professional matters, work undertaken, ethics, morality, as well as the designed punishment in the event of disobeying the rules. Simultaneously with issuing instructions, legal provisions and regulations specifying the rights and obligations of midwives, the authorities of larger cities began introducing the position of municipal midwives. These midwives were obliged, among others, every year to help a few poor women indicated by the municipal authorities to deliver their babies and to report each child born with their help to the parish office or other office for entry in the book of births [31].

The number of women in training increased significantly, and by 1894 there were already 50 students. The lectures for midwives and other students were still conducted jointly, which aggravated the already difficult learning conditions. Professor H. Jordan saw their improvement in the creation of separate self-study courses for midwives. He submitted the application for this form of training for midwives in Krakow still as the Dean of the Faculty of Medicine, on 9 November 1894, in a letter to the ImperialRoyal Ministry of Religions and Public Enlightenment. The response to the application was positive, and on 27 February 1895 a special official act separated the midwifery school from the obstetric and gynaecological clinic. A separate act of 5 November 1895, of the Imperial-Royal Ministry of Religious Affairs and Public Enlightenment, addressed to the Dean's Office of the Faculty of Medicine of the Jagiellonian University, allowed the start of a self-study course for midwives in Krakow in the winter term of the year 1895/96. The administration of the new independent institution was entrusted to Prof. Dr. Antoni Mars [14, 38].

Henryk Jordan remained the head of the hospital ward. Professor Antoni Noga-Mars was assigned an assistant to help him in running the school. The first assistant, selected in a competition, was doctor Franciszek Koźmiński.

The act also recommended that the necessary adaptations be made in the maternity ward of the hospital of St. Lazarus. One hundred Polish zlotys were allocated to cover the costs of adaptation and fifty zlotys for the purchase of new teaching aids. These measures were very modest and only to a small extent allowed improvement of material learning conditions.

The teaching aids previously used in the clinic to teach midwives were to be used in the newly separated school, as recommended in the abovementioned Act of the Imperial-Royal Ministry of Religious Affairs and Public Enlightenment [Ministerstwo Wyznań i Oświecenia Publicznego]. The first head of the new 
independent institution, in a letter to Prof. H. Jordan, presented the difficult educational conditions and described considerable deterioration and even destruction of the aids used so far.

From the academic year 1895/96, midwives were trained separately from medical students. The classes were still conducted at the Obstetric Clinic and under the academic supervision of the Faculty of Medicine. The ceremony of granting a part of the Obstetrics and Gynaecology Clinic of St. Lazarus for training purposes was solemnly held on 1 January 1896, in the presence of government and university authorities. University representatives at this ceremony were: Prof. Aleksander Rosner - Deputy Dean of the Faculty of Medicine, Prof. Stanisław Ponikło - the Head of St. Lazarus Hospital, Prof. Henryk Jordan - the Medical Director of St. Lazarus Hospital, and Prof. Antoni Mars and Bronisław Bieńkowski - the Hospital Counsellors [14]. The importance of carrying out this idea promoted by Prof. Henryk Jordan for the further development of midwives in Krakow is worth emphasising. The independent institution took the name of the Imperial Royal School of Midwives [Cesarsko-Królewska Szkoła Położnych]. As already mentioned, despite the subsidies received earlier and the preparations made, the facility started operating with insufficiently sized premises.

On the other hand, the school's development was supported by the changing political situation in the Galician Autonomy, which, although it gave only limited freedom, enabled the unfettered development of Polish education. Midwifery training developed very well. The letters sent by Prof. Mars to the Dean of the Faculty of Medicine and Governorship in Lviv show that in the year $1895 / 96$ as many as 81 students were trained. In the following years, the numbers varied (in 1895 - 52, in 1896 - 81, in 1897 - 54, and in 1898 - 56 students) [30, 39]. The possibility of applying for scholarships provided by municipal councils or commune foundations also favoured the development of midwifery training.

In the clinic, after starting the independent midwifery training, there was a division of beds into school and clinical ones. The independent school had 33 beds and two lecture halls. The duties of a school midwife were performed by the ward III midwife - a subordinate to the professor of the midwifery school during education, and during the holidays subordinate to the medical director of the ward.

In 1898, Prof. Antoni Mars became a professor of obstetrics and gynaecology at the University of Lviv and the head of the university clinic there, which resulted in his transfer to Lviv together with his assistant. From 1 October 1889, Dr. Aleksander Rosner became the head of the midwifery school at the request of the Dean of the Faculty of Medicine (Prof. Henryk Jordan). In turn, the position, which was vacant af- ter seven years of Prof. Rosner's administration, was recommended by the Imperial-Royal Ministry of Religions and Public Enlightenment to be filled in a competition, entrusting the temporary management to Dr. Stanisław Dobrowolski. In 1912, he published the textbook "Obstetric Training for the Use of Midwives", which was widely used. When Dobrowolski died in 1917, his assistant Ada Markowa replaced him as head of the midwifery school $[11,14]$. She trained and educated several generations of midwives, took care of the school's development, and had the title of Doctor of Universal Medicine and Doctor of Surgery (obtained at medical studies in Zurich).

At the turn of the twentieth century, the JagielIonian University was a European-quality university, one of the best within the boundaries of the AustroHungarian Monarchy at that time, which boded well for the future, also for the midwifery school operating under the supervision and patronage of the Faculty of Medicine.

\section{Disclosure}

The authors declare no conflict of interest.

\section{References}

1. Chamcówna M. Uniwersytet Jagielloński w dobie Komisji Edukacji Narodowej Szkoła Główna Koronna w okresie wizyty i rektoratu Hugona Kołłątaja 1777-1786. Zakład Narodowy im. Ossolińskich, Wrocław 1957; 14.

2. Żeleńska-Chełkowska A. Kołłątajowskie koncepcje organizacji Uniwersytetu. In: W kręgu wielkiej reformy. Mrozowska K, Dutkowa R (eds.). PWN, Warszawa 1977; 125.

3. Stopka K, Banach AK, Dybiec J. Dzieje Uniwersytetu Jagiellońskiego. Wyd. UJ, Kraków 2000.

4. Chamcówna M. Dzieje uniwersytetu Jagiellońskiego w latach 1765-1850. PWN, Kraków 1965.

5. Dziedzic S. Portrety Niepospolitych. Wyd. Petrus, Kraków 2013; 309-330.

6. Badurski A. Propositio instituendi Collegi Medici causa facta; a reformatio hodierno medicae artis Studio petita, atque opportuniori modo ordinationis accommodata a. 1776. Rocznik Wydziału Lekarskiego w Uniwersytecie Jagiellońskim 1840; 3: 36.

7. Leśniak F. Profesor Andrzej Badurski w służbie wielkiej reformy. Szpital kliniczny św. Barbary w Krakowie. In: Komisja Edukacji Narodowej. Kontekst historyczno-pedagogiczny. Dormus K, Popiołek B, Chłosta-Sikorska A, Ślęczka A (eds.). Wyd. Wydziału Pedagogicznego Uniwersytetu Pedagogicznego im. KEN, Kraków 2014; 218-222.

8. Głębocki JT. Zakłady ku ulżeniu cierpieniom bliźnich obecnie w Krakowie istniejące. Z krótką wzmianką o dawniejszych, a dziś nie istniejących instytucyach tego rodzaju. Drukarnia "Czas", Kraków 1852; 332.

9. Szumowski W. Krakowska Szkoła Lekarska po reformach Kołłątaja. Towarzystwo Miłośników Zabytków Krakowa, Kraków 1929; 258-259.

10. Wachholz L. Wydział Lekarski Uniwersytetu Krakowskiego i jego grono nauczycielskie od r. 1364-1918. Kraków 1935.

11. Waszyński E. Historia położnictwa i ginekologii w Polsce. Volumed, Wrocław 2000; 53-66. 
12. Stawiak-Ososińska M. Rys historyczny kształcenia akuszerek w Krakowie (do 1914 roku). In: Galicja i jej dziedzictwo. Tom 20. Historia wychowania. Misja i edukacja. Dybiec J, Szmyd K (eds.). Wydawnictwo Uniwersytetu Rzeszowskiego, Rzeszów 2008; 310.

13. Stawiak-Osińska M. Udział państw zaborczych w tworzeniu pierwszych szkół dla akuszerek na ziemiach polskich na przełomie XVII i XIX wieku. In: Państwo a edukacja. Kochanowicz J, Tokarz T (eds.). Wyd. Naukowe Dolnośląskiej Szkoły Wyższej, Wrocław 2008; 3: 133-140.

14. Wachholz L. Szpitale krakowskie 1220-1920. Część II. Biblioteka Krakowska 1924.

15. Świtalski L. Sprawozdanie z oddziału ginekologicznego kliniki ginekologiczno-położniczej UJ pod kierunkiem Dra H. Jordana z roku szkolnego 1893/4. Przegl Lek 1895; 1: 34.

16. Śliwiński S. Projekt nowoczesnej reformy fakultetu medycznego w Krakowie z r. 1777 (w 200-setną rocznicę projektu reformy). Wiad Lek 1977; 24: 1928.

17. Badurski A. Odpowiedzi na pytania podane od JW JMci Xiędza Kołłątaja kanon. krak. delegowanego od prześwietnej Kommissyi edukacyjnej do Akademii krakowskiej, dotyczące stanu i dziejów facultatis medicae d. 16 lipca 1777. Rocznik Wydziału Lekarskiego w Uniwersytecie Jagiellońskim 1840, 3: 32-35.

18. Arch. UJ, Fasc. 445. Nr 11.206.

19. Gajda Z. Rys historii nauczania medycyny w Krakowie. In: Dzieje nauczania medycyny na ziemiach polskich. Żydowo M (ed.). PAU, Kraków 2001; 130-132.

20. Filar Z. U kolebki polskiego położnictwa klinicznego. Położna 1957; $2: 3$

21. Schwarz S. Nauka i nauczanie położnictwa i chorób kobiecych w Krakowskim Wydziale Lekarskim. Polski Tygodnik Lekarski 1964; 13: 481.

22. Stawiak-Ososińska M. Sztuka położnicza dla kobiet: kształcenie akuszerek na ziemiach polskich w dobie niewoli narodowej (1773-1914). Wyd. DiG, Warszawa 2019; 310.

23. Kołłataj H. Raporty o wizycie i reformie Akademii Krakowskiej. Wstęp i komentarz: M. Chamcowna. Zakład Narodowy im. Ossolińskich, PAN, Wrocław 1967; 99.

24. Świeboda J. Średnie szkolnictwo medyczne w Galicji. Archiwum Historii Medycyny 1995, 58: 397-409.

25. Kwaśnicki A. Rozwój nauk i nauczania w Wydziale Lekarskim Uniwersytetu Jagiellońskiego w XIX stuleciu. Nowiny Akuszeryjne $1905 ; 7$.

26. Arch. UJ, Paso. 26 a Nr 419.

27. Kronika Uniwersytetu Jagiellońskiego od r. 1864 do r. 1887. Obraz jego stanu dzisiejszego wraz z rzeczą o rektorach od czasów najdawniejszych. Drukarnia UJ, Kraków 1887; 57-87.

28. Arch. UJ, sygn. WL II 314 (Materiały archiwalne oddziału gin. Szpitala św. Łazarza oraz Szkoły Położnych).

29. Prokop KR. Alma Mater Cracoviensis 1364-2014. KrakówPilica 2014; 176-190.

30. Arch. UJ, sygn. WL I 96-98 (Akta akuszerek).

31. Matuszewska E. Rozwój szkół położniczych na ziemiach polskich od połowy XVIII do końca XIX wieku - przepisy prawne normujące pracę położnych. W: Zarys historii zawodu położnej. Matuszewska E (ed.). Wyd. REA, Warszawa 2012; 55-84.

32. Arch. UJ, sygn. 445, nr 11211-11213.

33. Gajda Z. Nauczanie medycyny na Wydziale Lekarskim Uniwersytetu Jagiellońskiego w dobie Rzeczypospolitej Krakowskiej. Wyd. IHN PAN, Wrocław 1978; 126-132, 336.

34. Morawski H. Historia Uniwersytetu Jagiellońskiego: Średnie wieki i odrodzenie, z wstępem o Uniwersytecie Kazimierza Wielkiego. Tom I-II. Kraków: sn; 1900.
35. Swarz S. Nauka i nauczanie położnictwa i chorób kobiecych na krakowskim Wydziale Lekarskim. In: Sześćsetlecie medycyny krakowskiej. Tom drugi. Historia katedr. W sześćsetlecie Uniwersytetu Jagiellońskiego. Tochowicz L (ed.). PWN, Kraków 1964; 297.

36. Rozporządzenie Senatu Rządz. z 21 III 1842, nr 338 DGS. Instrukcja dla akuszerek praktykujących w Mieście Krakowie i Okręgu, WMK VI-58, k. 459-460 (art. 1, 3-4). Druk urzędowy. In: AUJ, „Chirurdzy niżsi i akuszerki XII 1800-III 1849”, WL I 100, k. nspg.

37. Pisarski T, Obara M, Waszyński E. Szkoły i twórcy współczesnej ginekologii polskiej. PTG, Poznań 1991; 9-10.

38. Łapiński Z. Narodziny i rozkwit nauki położniczej w Krakowie. Ginekol Pol 1977; 48: 303-310.

39. Arch. UJ, sygn. WL-588 Akta osobowe położnych z lat 1849-1897. 